\title{
Identification of Flavonoids in Iraqi Date Palm Pollen by HPLC
}

\section{RAFAH RAZOOQ AL-SAMARRAI ;ABDUL-MONAIM HAMAD AL -SAMARRAI ${ }^{1}$ and FERAH GHALI AL-SALIHI ${ }^{2}$}

\begin{abstract}
'Department of Chemistry, College of Education, Samara University, Samara , Iraq. 2Department of Chemistry, College of Education for women, Tikrit University ,Tikrit, Iraq. ${ }^{\star}$ Corresponding author E-mail: dr.rafah_alsamarrai@uosamarra.edu.iq
\end{abstract} http://dx.doi.org/10.13005/ojc/330252

(Received: December 22, 2016; Accepted: February 27, 2017)

\begin{abstract}
Date palm pollen-DPP (Phoenix dactylifera $\mathrm{L}$ ) plays an important role in traditional treatment in Iraq, especially for the treatment of fertility or as supplements, flavonoids were important components for date palm pollen, no information is available in the literature about the types of flavonoids in an Iraqi DPP variety El-Ghannmi Ahmar. The HPLC analysis revealed that in an Iraqi DPP variety El-Ghannmi Ahmar contains many types of flavonoids $(13.590 \mu \mathrm{g} / \mathrm{g}$ lincoceric acid, $122.251 \mu \mathrm{g} /$

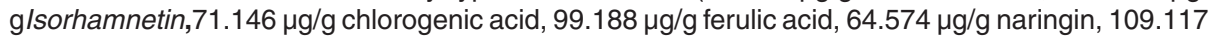
$\mu \mathrm{g} / \mathrm{g}$ apigenin, $48.391 \mu \mathrm{g} / \mathrm{g}$ apigenin-7-O-beta glycopyranoside, $28.883 \mu \mathrm{g} / \mathrm{g}$ letulin and $18.291 \mu \mathrm{g} / \mathrm{g}$ letulin-7-O-beta glycosides).
\end{abstract}

Key words: El-GhannmiAhmar, Date palm pollen, Flavonoids

\section{INTRODUCTION}

Date Palm Pollen (Phoenix dactylifera, L.)-DPP is a fine, powder-like material produced by flowering plants and gathered by bees ${ }^{1}$, it is very important causing of human respiratory allergic disorders, involving the production of immunoglobulins and hence the release of histamine and other chemicals ${ }^{2,3}$. The early Egyptians and ancient Chinese used pollen as a rejuvenating medicinal agent. It has been called a "fountain of

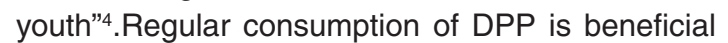
in nephropathy, rheumatism,gastropathy, sexual debilityand DPP extract have potential protective effects on testicular dysfunction induced by altered thyroid hormones ${ }^{5,6}$. In addition DPP grains have antioxidant and hypolipidemic effect in which exhibited significant reduction for serum cholesterol and low density lipoptoein-cholesterol(LDL-C), triglycerides and improve the level of high density lipoprotein-cholesterol( HDL-C), also the isolated flavonoids from DPP have anti atherosclerotic effects in high dose ${ }^{7}$.

Phytochemical screening showed that dried DPP contain sterols, flavonoids, triterpenoidal, saponins, tannins, and crude gonadotrophic substance [Egyptian cultivar] ${ }^{2,8,9}$, while in El- 
Ghannmi Ahmar DPP[Iraqi cultivar] phytosterols, alkaloids, protein, carbohydrates, glycosides, phenolic compounds, tannins, terpenoids, saponins, coumarins, lignin and flavonoids ${ }^{10}$.

Many types of flavonoids has been identified in DPP, Abbas \& Ateya ${ }^{11}$ indicated five flavonoids compounds [rutin, luteolin -7-O- $\beta$-D - glucoside, apigenin, isorhamnetin-3-O- glucoside and naringin were isolated for the first time from the pollen. While Daoud et al found that the Tunisian cultivar contain higher concentrations of flavonoids than Kerkennah cultivar, which was about twice as high, especially in the acetone extract, and four types of flavonoids were identified in Tunisian cultivars by HPLC, which include Quercitin, Rutin, Catechin and Epicatechin ${ }^{12}$. So that the aim of this study is to identify the flavonoids inElGhannmi Ahmar DPP[Iraqi cultivar].

\section{MATERIAL AND METHODS}

\section{Plant material}

DPP (Phoenix dactylifera L.) variety El-Ghannmi Ahmar was collected from Samarra city,Salah Al-Din,Iraq separated from the kernels by fine gauze sieve and left in an incubator at $35^{\circ} \mathrm{C}$ for 3 hours.

\section{Methods}

Extraction and isolation of flavonoids (Ex-F) was done according to ${ }^{13}$ method with some modification, while the chromatographic analyses for Ex-F was performed by HPLC (Shimadzu,10AVLC,Japan) according to the method of the ${ }^{14}$ with some

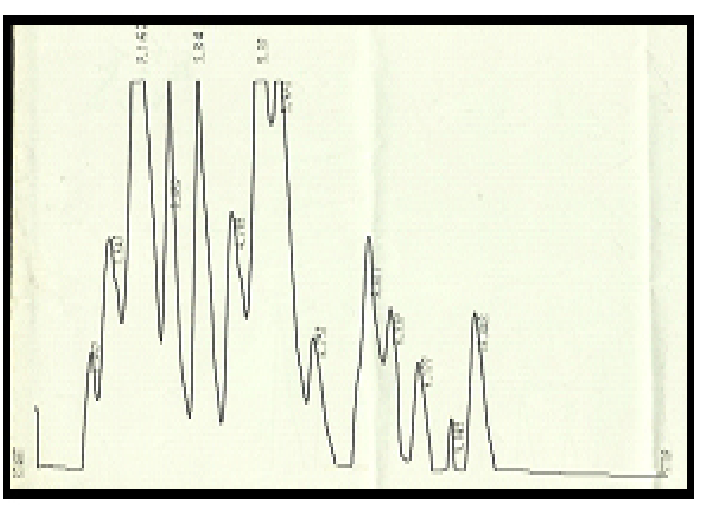

Fig. 1: HPLC Analysis of Isolated Flavonoids from Iraqi DPP modification by using C-18 column (150-4.6mm, $5 \mathrm{~mm})$. The mobile phase consisted solvent of $0.1 \%$ acetic acid in deionized water and acetonitrile at a ratio (20:80). The UV detection wavelength and the flow rate were $264 \mathrm{~nm}$ and $0.9 \mathrm{ml} / \mathrm{min}$, respectively. In which isolated flavonoids was dissolved in methanol(HPLC grade) at a final concentration of $100 \mu \mathrm{g} / \mathrm{ml}$ and then filtered through a membrane filter $(0.45 \mu \mathrm{m}$ pore size) prior to injection. Twenty microliter of Ex-F sample was injected on C18-HPLC column.

Ten stander solutions $(25 \mu \mathrm{g} / \mathrm{ml})$ were used (lignoceric acid, isorehamanetin, chlorogenic acid, ferulic acid, naringin, apigenin, apigenin 7-O-betaglycopyranoside, rutin, leteolin, leteolin-7-O-beta glycosides). The concentration of identified flavonoids was done according to the following equation:

Conc. of $=\frac{\text { Area of sample }}{\text { flavonoids }(\mu \mathrm{g} / \mathrm{ml})}$
Area of stand.
C=Conc. of standard solution
$D=$ Dilution factor

RESULTS

The HPLC analysis of flavonoids in the Iraqi date palm pollen was carried out which showed 14 peaks fig.(1) with different $R_{t}(1.257,1.647,2.167$, 3.052, 3.84, 4.795, 5.37, 5.923, 6.757, 8.017, 8.532, $9.177,9.945$ and 10.443) $\mathrm{min}$ and the area for each peak were 23998, 51700, 142188, 74231, 130242 ,

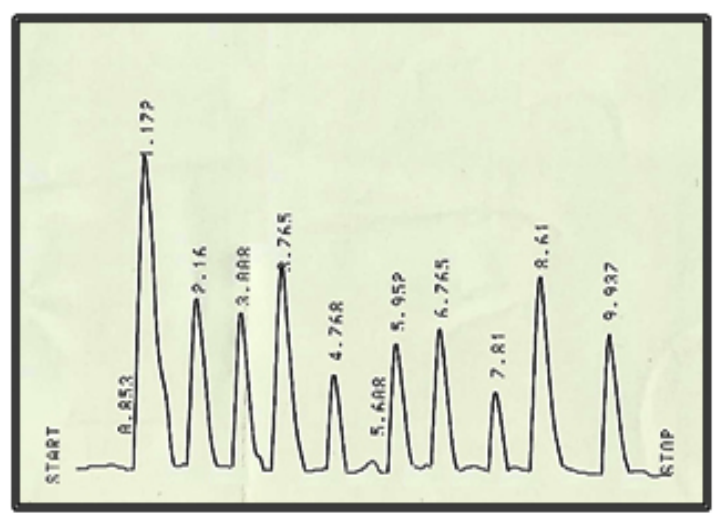

Fig. 2: HPLC Analysis of 10 Standard Flavonoids 
Table 1: Retention Times and Area Under Curves for Iraqi DPP Flavonoids

\begin{tabular}{|c|c|c|c|}
\hline Rt. (min) & Area & $\begin{array}{l}\text { Identified } \\
\text { compounds }\end{array}$ & $\begin{array}{l}\text { Conc. } \\
(\mu \mathrm{g} / \mathrm{g})\end{array}$ \\
\hline 1.257 & 23998 & Lignoceric acid & 13.590 \\
\hline 1.647 & 51700 & Unknown & - \\
\hline 2.167 & 142188 & Isorhamnetin & 122.251 \\
\hline 3.052 & 74231 & Chlorogenic acid & 71.146 \\
\hline 3.84 & 130242 & Ferulic acid & 99.188 \\
\hline 4.795 & 57145 & Naringin & 64.574 \\
\hline 5.37 & 105805 & Unknown & - \\
\hline 5.923 & 100658 & Apigenin & 109.117 \\
\hline 6.757 & 48629 & $\begin{array}{c}\text { Apigenin-7-O- } \\
\text { beta glycopyranoside }\end{array}$ & 48.391 \\
\hline 8.017 & 62767 & Unknown & - \\
\hline 8.532 & 38544 & Letulin & 28.883 \\
\hline 9.177 & 35117 & Unknown & - \\
\hline 9.945 & 17723 & $\begin{array}{l}\text { Letulin-7-O- } \\
\text { beta glycosides }\end{array}$ & 18.291 \\
\hline 10.443 & 74470 & Unknown & - \\
\hline
\end{tabular}

57145, 105805, 100658, 48629, 62767, 38544, 35117,17723 and 74470 which summarized in table (1).

The chromatogram of the ten standard flavonoids and phenolic compounds (lignoceric acid , isorhamnetin, chlorogenic acid, ferulic acid, naringin, apigenin, apigenin-7-O-beta glycopyranoside, rutin, letulin and letulin-7-O-beta glycosides) were shown in the Fig(2).

The $R_{t}$ of the ten standard peaks were $(1.172,2.16,3.008,3.765,4.768,5.952,6.765,7.81$, 8.61 and 9.937) $\mathrm{min}$ and the areas were 44148, 29077, 26084, 32827, 22124, 23062, 25123, 16414, 33362 and 24223 respectively, table(2).

Results obtained from chromatograms of DPP and compared with chromatogram of ten standard flavonoids and phenolic compounds, as shown in Fig.(2) and its $R_{t}$ value in table(2), indicate that DPP contained $13.590 \mu \mathrm{g} / \mathrm{g}$ ligncoceric acid, $122.251 \mu \mathrm{g} / \mathrm{g}$ /sorhamnetin, $71.146 \mu \mathrm{g} / \mathrm{g}$ chlorogenic acid, $99.188 \mu \mathrm{g} / \mathrm{g}$ ferulic acid, $64.574 \mu \mathrm{g} / \mathrm{g}$ naringin, $109.117 \mu \mathrm{g} / \mathrm{g}$ apigenin, $48.391 \mu \mathrm{g} / \mathrm{g}$ apigenin-7-O-
Table 2: Retention Times and Area Under Curves for Standard Flavonoids

\begin{tabular}{lcc}
\hline Standard & Rt. (min) & Area \\
\hline Lignoceric acid & 1.172 & 44148 \\
Isorhamnetin & 2.16 & 29077 \\
Chlorogenic acid & 3.008 & 26084 \\
Ferulic acid & 3.765 & 32827 \\
Naringin & 4.768 & 22124 \\
Apigenin & 5.952 & 23062 \\
Apigenin-7-O- & 6.765 & 25123 \\
beta glycopyranoside & & \\
Rutin & 7.81 & 16414 \\
Letulin & 8.61 & 33362 \\
Letulin-7-O- & 9.937 & 24223 \\
beta glycosides & & \\
\hline
\end{tabular}

beta glycopyranoside, $28.883 \mu \mathrm{g} / \mathrm{g}$ letulin and 18.291 $\mu \mathrm{g} / \mathrm{g}$ letulin-7-O-beta glycosides with absence of rutin, table (1). The other unknown peaks may indicate other type of flavonoids, so that we need to use other type of flavonoids as standard and more modern techniques such as GC, GC-MS, HPLC-MS or NMR for analysis the flavonoids type in DPP.

Results are consistent with the previous study of ${ }^{11}$, which indicates the presence of many types of flavonoids in Egyptian DPP naringen, luteolin -7- O- $\beta$-D - glucoside, apigenin, isorhamnetin - 3 -O- glucoside and rutin which isolated them by silica gel column chromatography and eluted by ethyl acetate, while the identification of these compounds were carried out by GC-MS and HPLC. Similarly, other study identified quercetin and rutin in DPP ${ }^{8}$.

No information were available in the literature about the DPP content of Isorhamnetin, luteolin, chlorogenic acid, ferulic acid and apigenin7-O-beta glycopyranoside. The content of flavonoids in pollen may be affected by many enviermintal factors such as, air pollution, in which Rezanejad study the effect of air pollution on flavonoids in pollen grains of some ornamental plants, and found that HPLC analysis demonstrated that air pollution induces flavonoids accumulation to significantly higher levels in the polluted pollen of ornamental plants than in the control ${ }^{15}$. 


\section{REFERENCES}

1. Basim, E.; Basim, H. and Ozcan, M. Antibacterial activities of Turkish pollen and propolis extracts against plant bacterial pathogens. J. Food Eng. 2006; 77: 992-996.

2. Mistrello,G.; Harfi, H.; Roncarolo, D.; Kwaasi, A.; Zanoni, D.; Falagiani, P and Panzani, R. Date palm pollen allergoid: characterization of its chemical-physical and immunological properties. Int. Arch. Allergy. Immunol_2008; 145(3):224-230.

3. Huertas, A.J.; Lopez-Saez, M.P. and Carnes, J. Clinical profile of a Mediterranean population sensitized to date palm pollen (Phoenix dactylifera).A retrospective study.Allergol. Immunopathol.(Madr).2011;39(3):145-149.

4. Kroyer, G. and Hegedus, N. Evaluation of bioactive properties of pollen extracts as functional dietary food supplement. Innovative Food Sci. Emerging Technol..2001;2(3):171174.

5. Elgindi, M.R.; Singab, A.N.; El-Taher, E.M. and Kassem, M. E. A Comprehensive Review of Phoenix (Arecaceae). RJPBCS.2015;6(3):96674.

6. El-Kashlan, A.M.; Nooh, M.M.;Hassan, W.A. and Rizk, S.M. herapeutic Potential of Date Palm Pollen for Testicular Dysfunction Induced by Thyroid Disorders in Male Rats. PLoS ONE.2015; 10(10):2-10.

7 Al-Salihi, F.G.; Majeed, A. H. and Hameed,R.R.Hypolipidemic effect of date palm pollen and isolated flavonoids in sera of adult male rabbits. Kerbala Journal of Pharmaceutical Sciences2013;5:34-45.

8. Mahran, G.H.; Abdul-Wahab, S.M. and Attia, A.M. Constituents of the Egyptian Date Palm Pollen: Saponin and Lipid Constituents of
Pollen Grains. First Int. Conf. vol.I, Zag.Univ. 1985.

9. Bosila, H.A., El-Sharabasy, S.F., Mohamed, S.M., Ibrahim I.A. and Refay K.A. Production of some secondary products from date palm tissue cultures (Sewi cultivar) using some precursors. I. Callus stage. The Second International Conference on Data Palms. P.85 Alain, United Arab Emirates 2001; 25-27.

10. Al-Samarai, A. H.; Al-Salihi, F.G. and AlSamarai, R.R. Phytochemical constituents and nutrient evaluation of date palm (Phoenix dactylifera, L.) pollen grains. Tikrit Journal of Pure Science.2016;21(1):56-62.

11. Abbas, A.F. and Ateya, A.M. Estradiol, esteriol,estrone and novel flavonids from date palm pollen. Aust. J. Basic Appl. Sci. 2011; 5(8):606-614.

12. Daoud, A; Malika,D;Bakari; S. et al. Assessment of polyphenol composition, antioxidant and antimicrobial properties of various extracts of Date Palm Pollen (DPP) from two Tunisian cultivars. Arabian Journal of Chemistry.2015;7:2-14.

13. Chen, J.J.; Li, X.R. and Fang, X. Purification of total flavones from Morus alba L. by macroporous adsorbents and kinetic model for the process. J. Zhejiang Univ. .medical Sciences 2006; 35: 219-223.

14. Tao, W.;Yang, N.;Duan, J.A.;Wu, D.;Guo, J.;Tang, Y.; Qian, D. andZhu, Z.Simultaneous determination of Eleven Major Flavonoids in the Pollen of Typha angustifolia by PLCPDAMS. Phytochem.Anal.2011; 22(5):121-129.

15. Rezanejad, F. Air pollution effects on flavonoids in pollen grains of some ornamental plants. Turk. J. Bot. 2012; 36 : 49-54. 